\title{
Women's Political Participation through Representation in The Legislature
}

\author{
Ratnia Solihah \\ Department of Political Science \\ Padjadjaran University, Bandung, Indonesia \\ ratniasolihah91@yahoo.co.id \\ Yusa Djuyandi \\ Department of Political Science \\ Padjadjaran University, Bandung, Indonesia \\ f_yusa@yahoo.com \\ Siti Witianti \\ Department of Political Science \\ Padjadjaran University, Bandung, Indonesia \\ siti_witianti@yahoo.com
}

\begin{abstract}
Women's involvement in the political process such as their representation in the legislature is a form of awareness of the political power of women. Women's involvement in the political process in Indonesia is minimal, given the low representation of women in the legislature. This is due to several internal and external factors as well as the direct constraints, fundamental constraints and structural barriers that affect them. To discuss this condition, a qualitative approach is used through literature studies and documentation on issues of women's political participation through representation in the legislature. The results indicate that the government as a policymaker has established Law No. 2 of 2008 and Law Number 10 The year 2008 to encourage women's representation in the legislature. In both laws, women have a $30 \%$ quota to participate in the legislature. While political parties play a role in accommodating women representation in the legislature. However, the representation of women in the legislature has declined based on the 2014 election results, while women legislative candidates increased compared with the 2009 elections. This was due to the failure of political parties to regenerate women legislative candidates, so the quantity and quality of women legislative candidates was deemed incapable as legislative members, due to issues of municipal elections and political candidates for legislative women. In addition, also due to several factors, both internal factors and external factors of women legislative candidates as well as women voters themselves.
\end{abstract}

Keywords-political participation; woman; representative; legislative

\section{INTRODUCTION}

The number of female population in Indonesia is demographically more than men [1]. ${ }^{1}$ Likewise, the number of female voters shows more than the male voters in the election. However, in the political process that amount is not a guarantee of women's representation significantly. Women's involvement in the political process in Indonesia is still very low. ${ }^{2}$ The low participation of women structurally can be seen from two things. First, the lack of representation of women in decision- making institutions. The CETRO report on the data and facts of Indonesian women's representatives in the 1999-2001 legislature showed that women represented only $9 \%$ of the DPR or 45 people from 500 members of the House of Representatives. ${ }^{3}$ Second, at least women who occupy political positions in political institutions (especially in central and regional legislative institutions).

Although the government has created several measures to encourage women's representation in legislative bodies, such as Law Number 2 year 2008 and Law Number 10 year 2008. However, in fulfilling the $30 \%$ quota of women's representatives in the political field is still very difficult to do filled by political parties. The party is still having difficulties in getting qualified cadres, so most political parties only place women in formal quota fulfillment, not as an effort to improve the actualization of women in the political sphere.

Women's activities in the political sphere, through their representation in the legislature, are influenced by the performance of political parties in presenting their candidates, in this case, women's political cadres are given a strategic role to voice women's aspirations and show their work, for women's progress and prosperity. Political parties have a very significant role in enhancing women's representation through cadres of women legislative candidates by preparing and facilitating women's political cadres to chew deeper in society, as well as facilitating them as legislative candidates with high electability and well-known in the region.

However, political parties have not maximally performed their role in increasing women's representation. Although structurally there are laws that regulate and encourage women's representation in the legislature, they cannot encourage and increase the number of female legislators, even in the 2014 election the number of female legislators declines.

Based on the above description, this paper will discuss Women's Political Participation through Women's Representation in Legislative Institution. 


\section{THEORETICAL FRAMEWORK}

Political participation is the activity of a person or group of people to actively participate in political life. This activity can be in the form of voting in the election, being a member of the party and so on. Herbert McClosky said that "Political participation is a voluntary activity of citizens in which they take part in the process of electing the ruler and directly or indirectly in the process of public policy formation". ${ }^{4}$

One of the benchmarks of political participation in a country is the election. But voting in elections is not the only form of political participation, but there are other forms such as attending a rally, contacting or lobbying with government officials or legislators, becoming party members or one of the social movements with actions that can directly influence government policy. In addition, political participation is also done by the individual itself, both male and female.

In relation to women's political participation, Budiardjo argues that women's political participation is divided into several forms, as observers, participants, activists, and apolitists. Woman's political participation as observers is shown in the form of voting. Women's political participation as participants is by participating in informal discussions, as campaign participants, becoming campaigners, witnessing the election. Women's political participation as an activist is to become a member of election organizer and as a party official. While the political participation of women as apolitical is not participating in elections and are indifferent to the world of politics. $^{5}$

Regarding the low political participation of women, Surbakti was quoted by Hadis as suggesting some obstacles internal barriers that can be seen from aspects of education, cultural culture, family, and women themselves. While internal barriers can be seen through socialization or direction, less important political views, and local roles in which environmental roles such as public figures in political participation do not encourage women to participate due to environmental factors. ${ }^{6}$

Meanwhile, according to $\mathrm{UNDP}^{7}$, the barriers to participation as well as women's representation in politics include:

a. Women's lack of belief in the political system, lack of political education and education, lack of knowledge of the system, lack of women's interest in politics, lack of financial resources, lack of confidence, lack of mobility, family responsibilities, lack of activism in political party cadres, support of political parties, perceptions that consider dirty politics.

b. The fundamental barriers include masculine culture and male dominance, men-centered political party agenda, lack of democracy in political parties, political commercialization, electoral system, nepotism and elitism in political parties, political violence, political corruption. c. Structural barriers, including private-public discursive dichotomy, public and private patriarchy, patriarchal social acts, religious Fundamentalism.

\section{RESEARCH METHOD}

This study uses qualitative approach through literature studies and documentation related to issues of women's political participation through their representation in the legislature. The literature study is conducted by collecting and reviewing the literature relevant to the issue under study, while documentation is conducted by reviewing various legislation and other documents as secondary data supporting discussion and analysis.

\section{RESULT AND DISCUSSION}

One manifestation of the increased awareness of women's political power is characterized by the active involvement of women in the political process. This political process can be pursued through the representation of women in politics. Women's representation in politics is based on Law Number 10 The year 2008 regarding General Election of DPR, DPD and DPRD Members as well as Law Number 2 The year 2008 concerning Political Party which contains mandate to political party to fulfill $30 \%$ quota for women in politic, especially in the representative body of the people.

For the 2014 election, the KPU has also issued various regulations to increase the representation of women in the political sphere, namely: 1). PKPU No. 7 of 2013 on the Rules for nominating DPR, Provincial DPRD and Regency / City DPRD, which affirms the $30 \%$ quota requirement in each Electoral District, including the serial number in which every three candidates must have one female candidate; 2) PKPU Number 15 Year 2013 which regulates campaign guidelines whereby billboards should not post photographs of legislative candidates but only party images, which are intended to protect women legislative candidates as most of them are unable to publicize on a large scale.

Undeniably, amidst the negative judgments that plagued legislative members both at the center and in the regions due to various cases that inevitably lowered public confidence in them, legislative elections remain an important agenda that is expected to bring better. Changes to Indonesia Therefore, public involvement in the political process becomes very important, including for women, both as voters and as legislative candidates.

Women's participation in the political process, especially in legislative elections can be done through voting activities, which to realize $30 \%$ of women's quota in the legislature, women as voters must also be smart in making choices. Without discriminatory intentions, women voters must also vote for women legislative candidates. But not just selecting women legislative candidates, but selecting women legislative candidates who have the skills and abilities that will ensure 
their function as legislators if elected, also have a good track record.

Although there are many ways for women to involve in the political process, in legislative elections there are two activities that will be prominent for the voters and the legislative candidates. As voters, women's political participation in legislative elections is seen in the choice of the majority of women voters in selecting their female representatives who are legislative candidates at both the central and regional levels. As legislative candidates, women's political participation is demonstrated by women's political capacities, opportunities and political roles or the role of legislative candidates capable of representing women and qualified to fight for the birth of policies to address women's issues. Thus, the inclusion of women at the level of power and legislation will strengthen women's access and control over development resource regulations. ${ }^{8}$

Despite several attempts by the government and women's organizations to improve women's representation in parliament, the results have not been as expected. In the 2014 legislative election, women representatives have declined in number as legislative candidates for elected women, while in nominations they have increased, in which each political party has fulfilled the $30 \%$ quota of women in the nomination of legislative members. This is indicated by the proportion of elected female legislators who failed to achieve $30 \%$ affirmative action in the 2014 election. In contrast, the proportion decreased from $18.2 \%$ in 2009 to $17.3 \%$ in 2014 . In fact, women candidates run, and the number of voters from political parties increased from $33.6 \%$ in 2009 to $37 \%$ in 2014. In 2014 legislative elections, women in the legislature were represented as much as 97 seats $(17.32 \%)$ in the House, 35 seats $(26.51 \%)$ in the DPD, and an average of $16.14 \%$ in the Provincial DPRD and $14 \%$ in the Regency / City DPRD. ${ }^{9}$

The issue of women's representation through legislative bodies on the one hand can be seen as the failure of political parties to regenerate legislative candidates from among women so that the quantity and quality of women legislative candidates is deemed incapable as a legislative member. In addition, the issue of capital and political electability of women legislative candidates is a factor affecting political parties in the process of nominating women cadres as legislative candidates.

On the other hand, the issue of women's representation through legislative bodies is not due to the failure of political parties to nominate female cadres as legislative candidates. But women legislative candidates are not elected as legislative candidates. The condition is influenced by several factors, including internal and external factors.

Viewed from internal factors of women legislative candidates, women's political representation in the legislature is influenced by their ability as legislative candidates, both regarding skills and economic capacity. Skills are needed by women in nominations for various purposes such as campaigning, political dialogue, political debate, communication with constituents, which leads to support for victory. Without this ability, women in parliament will only be seen as a complement and accessory for male legislators whose role is already outstanding. This affects the popularity and elektabilitas of female legislators in the next election.

From the internal factors of voters, the low representation of women in the legislature is due to the low knowledge of women about politics and the low interest of women voters to elect women legislative candidates. This is also due to the inability of women legislative candidates in representing the needs of women constituents in the election areas of women legislative candidates, leading to female voters being pragmatic.

From the external factors of women legislative candidates, it can be seen from a social perspective, where the involvement of women in nominations is often limited by higher patriarchal cultures considered men in various aspects.

From the external factors of women voters, it can be seen through several approaches that influence the behavior of women voters in their choice. In general there are several approaches in voting behavior that is sociological approach, psychological approach, and rational approach. ${ }^{10}$

The sociological approach looks at the background of a person or group of people based on gender, social class, race, ethnicity, religion, occupation, even area of origin that influences his decision variables to vote on election. ${ }^{11}$ The psychological approach is an emotional bond with a political party, an orientation on the issue and an orientation towards the candidate. ${ }^{12}$ The inspirational factors of the candidate can influence the attitude of women voters. Meanwhile, with a rational voter approach, voters have consideration of what to gain/lose if they decide to vote for a particular party or candidate. The rational approach of voters shows the pragmatic attitude of the voters in their choice, including the pragmatic attitude of women voters in choosing their representatives who are not from among women themselves.

\section{CONCLUSION}

Women's representation in the legislature is one of the manifestations of increasing awareness of the political power of women. Women's involvement is not only based on their participation in decision-making but also their contribution to the struggle for women's rights.

Various efforts have been made to encourage women's representation in the legislative elections in 2014. Where to participate in political parties in elections, political parties must meet the $30 \%$ quota of women legislative candidates. However, the results show that the maximum number of women representations has not been achieved through the legislature.

To address issues related to several internal and external factors affecting the non-achievement of $30 \%$ of women legislative candidate quotas in the legislature, several attempts 
by political parties, women legislative candidates and KPUs are needed to provide socialization and improvement of political education. Women voters, mainly due to the lack of skills or capacity of female legislative candidates to compete in elections, the lack of participation of female legislative candidates in their electoral communities, the low knowledge and political understanding of female voters about women and pragmatic legislative candidates while the attitude that led to the absence of female voter participation policy programs related to women's interests and women's issues so far.

\section{REFERENCES}

1 CIA World Factbook, https://www.indonesia-investments.com/id/ budaya/penduduk/item67?/ [Accessed on August 31, 2017]

2 Badan Pusat Statistik, "Data Penduduk", http://sp2010.bps.go.id/ [Accessed on August 31, 2017]

3 Sahi, Nirmala. Afrianti. "Studi Partisipasi Politik Perempuan". https://ejournal.unsrat.ac.id/index.php/jia/article/download/ 6278/5799

4 McClosky, Herbert, "Political Participation", Miriam Budiardjo, Partisipasi dan Partai Politik, Jakarta: PT Gramedia, 1981, pp. 1. Budiardjo, Miriam, Dasar-Dasar ilmu Politik. Jakarta: PT. Gramedia Pustaka Utama, 1992, pp. 5-6.

6 Hadis, Liza, Perempuan dalam Wacana Politik Orde Baru. Jakarta: LP3ES, 2004, pp. 404.

${ }^{7}$ Indonesia, "Partisipasi Perempuan dalam Politik dan Pemerintah. Jakarta: UNDP, 2010."

8 Jurnal Perempuan Edisi Ke 34. Politik dan Keterwakilan Perempuan. Jakarta: Yayasan Jurnal Perempuan, 2004.

9 Manafe, Dina, http://www.beritasatu.com/nasional/210327-kuota-30keterwakilan-perempuan-di-parlemen-gagal-tercapai, 2016.

10 Plano, Jack C, Kamus Analisa Politik, Jakarta: Rajawali Press, 1985.

11 Irmayani, T. "Perilaku Perempuan Pemilih dalam Menetapkan Pilihan pada Pemilu 2009", Jurnal Politeia Ilmu Politik (Volume 4, Number 1, 2012), Pp.14

12 Ibid 